\title{
KEKUATAN BAHASA DALAM KARYA FIKSI
}

\author{
Sri Wahyuni \\ Fakultas Sastra, Universitas Muslim Indonesia \\ Jalan Urip Sumoharjo KM 5, Makassar \\ Email: uniioningg15@gmail.com
}

\begin{abstract}
Abstrak: Bahasa dalam sastra mengemban fungsi utamanya sebagai fungsi komunikatif. Sastra, khususnya fiksi, di samping sering disebut dunia dalam kemungkinan, juga dikatakan sebagai dunia dalam kata. Hal itu disebabkan "dunia" yang diciptakan, dibangun, ditawarkan, diabstraksikan, dan sekaligus ditafsirkan lewat kata-kata, dan lewat bahasa. Perlu disadari bahwa bahasa bukan benda mati seperti batu, tembaga, dan cat, melainkan ciptaan manusia yang mempunyai muatan budaya dan linguistik dari kelompok pemakai bahasa tertentu.Bahasa sastra adalah bahasa yang dapat memengaruhi, membujuk dan pada akhirnya memikat pembacanya. Bahasa merupakan tata nama yang berupa daftar kata. Hal itu muncul berdasarkan gagasan sederhana bahwa dunia berikut isinya diatur sesuai dengan pandangan manusia. Masing-masing daftar kata itu mau tidak mau menerima satu sebutan di dalam setiap bahasa. Karena itu, bahasa adalah deretan kata-kata yang digunakan oleh suatu bangsa untuk mengungkapkan keinginan atau maksudnya.Demikian juga bahasa dapat berubah di bawah tekanan berbagai kebutuhan dan di bawah pengaruh masyrakat lain. Apapun yang akan dikatakan pengarang atau sebaliknya ditafsirkan oleh pembaca, mau tidak mau harus bersangkut paut dengan bahasa. Untuk memperoleh efektivitas pengungkapan, bahasa dalam sastra disiasati, dimanipulasi, dan didayagunakan secermat mungkin sehingga tampil dengan sosok yang berbeda dengan bahasa nonsastra.
\end{abstract}

Kata kunci: Bahasa, unsur fiksi, fiksi

\section{PENDAHULUAN}

Pada usia muda mereka mulai mengenali sifat-sifat "sastra" serta unsurunsur yang dengan teratur selalu muncul kembali. Mereka mengenal puisi dalam bentuk rima, sajak dolanan anak-anak, dan lagu-lagu. Bentuk-bentuk sastra seperti dongeng, drama, dan sajak-sajak ternyata cepat dikenali anak-anak. Anak-anak balita lebih suka bercerita dan lebih suka lagi mendengarkan sebuah cerita atau dongeng. Dari televisi mereka mengenal sebuah bentuk campuran antara cerita dan drama. Mereka sendiri juga diajak bermain drama atau pentas untuk anak-anak, dan khusus di pulau Jawa mereka berkenalan dengan dunia wayang dan watak-watak tertentu. Dan kemudian hari mereka belajar membedakan antara cerita fiksi dan laporan peristiwa yang sungguh-sungguh terjadi.

Bahasa merupakan komponen terpenting dalam kehidupan manusia. Manusia tidak akan bisa melanjutkan kelangsungan hidup mereka dengan baik dan teratur tanpa adanya bahasa. Mereka tidak bisa berinteraksi dengan mudah dan baik jika mereka tidak menguasai bahasa antara satu sama lain dan dengan tidak adanya kesinambungan tersebut mereka juga tidak dapat menangkap ekspresi kejiwaan maupun keinginan yang diutarakan oleh lawan komunikasinya. Gaya bahasa merupakan cara pengarang memilih, menata, dan menempatkan kata dalam susunan kalimat sehingga memiliki pengaruh atau efek tertentu bagi pembaca. 
Keraf (1994:113) menyatakan bahwa gaya bahasa merupakan cara menungkapkan pikiran melalui bahasa secara khas yang meperlihatkan jiwa, perasaan, dan kepribadian pengarang.

Bahasa dalam masyarakat umum sangat berbeda dengan bahasa yang ada dalam prosa. Walaupun secara tertulis itu sama, akan tetapi sangat berbeda dengan maksud yang akan dituju. Secara tidak langung pengarang berpikiran yang tidak sama dengan pembaca. Oleh karena itu setiap penganalisisan karya sastra khususnya prosa fiksi, pasti perlu adanya analisis bahasa sebelum diterjunkan ke layar lebar.

Gaya bahasa merupakan wujud pikiran dan perasaan pengarang dalam karyanya, sedangkan keindahan timbul dari pikiran yang dalam dan murni, dari pikiran yang luas dan mengethaui batas-batas melahirkannya pada menulis (Retnaningsih 1983:24). Sementara itu, Slamet Muljana (dalam Pradopo, 1997:93) menyebutkan bahwa gaya bahasa adalah susunan perkataan yang timbul atau hidup dalam hati penulis sehingga ketika diekspresikan akan menimbulkan perasaan atau efek tertentu bagi pembaca karya sastra. Hal ini juga yang menyebabkan adanya sekat dan kurang terkaitnya emosional satu sama lain. Bisa dikatakan bahwa bahasa sebagai salah satu kebutuhan primer yang mempunyai peran sebagai pengatur sirkulasi kelanjutan hidup. Bahkan, bahasa juga dapat dikategorikan sebagai senjata yang paling ampuh untuk membentengi diri dan negeri dari ancaman-ancaman perpecahan.

Berbahasa merupakan kegiatan yang selalu mengisi berbagai bidang kehidupan manusia, baik bidang ekonomi, hukum, politik, dan pendidikan. Kegiatan tersebut dapat berlangsung secara transaksional maupun interaksional. Dengan bahasa, seseorang dapat menyampaikan ide, pikiran, perasaan atau informasi kepada orang lain, baik secara lisan maupun secara tulisan.

Di era globalisasi saat ini penggunaan bahasa sebagai media komunikasi sangatlah terpengaruh oleh laju perkembangan teknologi dan informasi. Terdapat dua pengaruh pada bahasa setelah terkontaminasi dengan adanya laju teknologi dan informasi yang sangat cepat yaitu pengaruh positif dan pengaruh negatif. Adapun pengaruh positif yang dapat diperoleh adalah dimana media teknologi informasi sangat memperlancar hubungan komunikasi antar sesame. Mereka dapat menyampaikan segala komunikasi jarak jauh maupun jarak dekat dengan sangat praktis dan efisien. Di pandang dari sisi lain, kemajuan teknologi dan cepatnya akses informasi juga mempunyai dampak negative yang sangat mempengaruhi kelangsungan dari bahasa yang telah kita miliki dan kita sepakati untuk menjadi bahasa pemersatu bangsa serta tanah air yaitu bahasa Indonesia. Dapat kita ketahui bersama bahwa, sekarang ini banyak bahasa pergaulan yang sangat berbeda dengan kaidah-kaidah kebahasaan. Dengan menurunnya kemampuan berbahasa masyarakat bangsa ini, secara tidak langsung juga akan mengurangi rasa nasionalisme yang tertanam pada diri mereka. Sehingga benteng pertahanan yang selama ini tebangun kukuh akan lebih mudah untuk diporak-porandakan oleh musuh.

Para ahli bahasa mulai sadar bahwa pengkajian bahasa tanpa mengaitkannya dengan masyarakat akan mengesampingkan beberapa aspek penting 
dan menarik, bahkan mungkin menyempitkan pandangan terhadap disiplin bahasa itu sendiri. Apabila kita mempelajari bahasa tanpa mengacu kepada masyarakat yang menggunakannya sama dengan menyingkirkan kemungkinan ditemukannya penjelasan sosial bagi struktur yang digunakan.

\section{PEMBAHASAN}

Manusia adalah makhluk sosial, sehingga manusia perlu berinteraksi dengan manusia lainnya. Pada saat manusia membutuhkan eksistensinya diakui, maka interaksi itu terasa semakin penting. Kegiatan berinteraksi ini membutuhkan alat, sarana atau media, yaitu bahasa. Sejak saat itulah bahasa menjadi alat, sarana atau media. Tiada kemanusiaan tanpa bahasa, tiada peradaban tanpa bahasa tulis. Ungkapan-ungkapan itu menunjukkan betapa pentingnya peranan bahasa bagi perkembangan manusia dan kemanusiaan. Dengan bantuan bahasa, anak tumbuh dari organisme biologis menjadi pribadi di dalam kelompok. Pribadi itu berpikir, merasa, bersikap, serta memandang dunia dan kehidupan seperti masyarakat di sekitarnya.

Dalam bahasa sastra juga perlu terdapat unsur keindahan agar pembaca tertarik untuk membacanya. Jika bahasa yang digunakan bagus atau menarik, apalagi isi cerita yang diceritakan menarik pembaca akan berusaha untuk meniru sikap yang baik seperti yang ada dalam cerita tersebut. Dalam sebuah novel pasti terdapat stile dan stilistika dan stile dan nada.

Menurut Gorys Keraf (2004:1), bahasa adalah alat komunikasi antara anggota masyarakat berupa simbol bunyi yang dihasilkan oleh alat ucap manusia. Ketika anggota masyarakat menginginkan untuk berkomunikasi dengan sesamanya, maka orang tersebut akan menggunakan suatu bahasa yang sudah biasa digunakannya untuk menyampaikan suatu informasi. Pada umumnya bahasa-bahasa tesebut dapat berbeda antara satu daerah dengan daerah yang lain, hal ini dapat dikarenakan adanya perbedaan kultur, lingkungan dan kebiasaan yang mereka miliki. Mungkin asumsi beberapa orang berpendapat bahwa tidak hanya bahasa saja yang dapat dijadikan sebagai media komunikasi. Mereka menunjukkan bahwa terdapat dua orang atau lebih yang mengadakan komunkasi dengan mempergunakan cara-cara tertentu yang telah disepakati bersama. Mereka memakai beberapa alat ataupun media untuk menyampaikan suatu kabar yang memang ingin diinformasikan kepada pihak lain dengan menggunakan lukisan-lukisan, asap api, bunyi gendang atau tong-tong, dan sebagainya.

Menurut KBBI (2016), bahasa adalah sistem lambing bunyi yang arbiter, yang dipergunakan oleh sekelompok masyarakat untuk bekerjasama, berinteraksi, dan mengidentifikasikan diri. Dilihat dari pengertian yang ada dalam kamus tersebut, dapat dipahami bahwa bahasa juga dapat berfungsi sebagai lambang bunyi sebagai mana not yang ada pada nada, akan tetapi fungsiatau manfaat yang diberikan sangatlah berbeda antara keduanya. Bunyi yang dihasilkan oleh bahasa diprioritaskan untuk menyampaikan suati informasi serta lebih menitik beratkan pada kepadatan isinya bukan pada fungsi estetika yang dihasilkannya.

Bahasa adalah sistem symbol dan tanda. Yang dimaksud dengan sistem simbol adalah hubungan simbol dengan makna yang bersifat konvensional. 
Sedangkan yang dimaksud dengan sistem tanda adalah bahwa hubungan tanda dan makna bukan konvensional tetapi ditentukan oleh sifat atau ciri tertentu yang dimiliki benda atau situasi yang dimaksud.

Dari beberapa definisi yang telah dipaparkan di atas maka dapat disimpulkan bahwa bahasa adalah alat untuk berkomunikasi yang dapat disampaikan melalui lisan, tulisan maupun media lain yang sudah disepakati oleh pihak yang berkomunikasi. Bahasa yang disampaikan melalui lisan dapat disebut dengan bahasa primer sedangkan bahasa yang diutarakan dengan menggunakan selain lisan disebut dengan bahasa sekunder.

Di daerah-daerah yang ada di Indonesia, masyarakat yang ada disana tidak hanya menggunakan satu bahasa saja, melainkan menggunakan beberapa bahasa yang berbeda satu daerah dengan daerah yang lain dan bias jadi walaupun mereka sama-sama orang yang notabenenya adalah penduduk yang tinggal menetap dalam satu pulau atau provinsi bisa jadi tidak paham dengan penyampaian lawan bicara dari daerah yang berbeda dalam satu pulau atau provinsi tersebut.

Secara umum sudah jelas bahwa fungsi bahasa adalah sebagai alat komunikasi. Bahasa sebagai wahana komunikasi bagi manusia, baik komunikasi lisan maupun tulis. Fungsi ini adalah dasar bahasa yang belum dikaitkan dengan status dan nilai sosial. Dalam kehidupan seharihari, bahasa tidak dapat dilepaskan dari kegiatan hidup masyarakat, yang di dalamnya sebenarnya terdapat status dan nilai-nilai sosial. Bahasa selalu mengikuti dan mewarnai kehidupan manusia seharihari, baik manusia sebagai anggota suku maupun bangsa.terkait hal itu, Santoso, dkk. (2004) berpendapat bahwa bahasa sebagai alat komunikasi memiliki fungsi sebagai berikut:

a. Fungsi informasi, yaitu untuk menyampaikan informasi timbal-balik antar anggota keluarga ataupun anggota-anggota masyarakat.

b. Fungsi ekspresi diri, yaitu untuk menyalurkan perasaan, sikap, gagasan, emosi atau tekanan-tekanan perasaan pembaca. Bahasa sebagai alat mengekspresikan diri ini dapat menjadi media untuk menyatakan eksistensi (keberadaan) diri, membebaskan diri dari tekanan emosi dan untuk menarik perhatian orang.

c. Fungsi adaptasi dan integrasi, yaitu untuk menyesuaikan dan membaurkan diri dengan anggota masyarakat, melalui bahasa seorang anggota masyarakat sedikit demi sedikit belajar adat istiadat, kebudayaan, pola hidup, perilaku, dan etika masyarakatnya. Mereka mentyesuaikan diri dengan semua ketentuan yang berlaku dalam masyarakat melalui bahasa.

d. Fungsi kontrol sosial, bahasa berfungsi untuk mempengaruhi sikap dan pendapat orang lain. Bila fungsi ini berlaku dengan baik, maka semua kegiatan sosial akan berlangsung dengan baik pula. Dengan bahasa seseorang dapat mengembangkan kepribadian dan nilai-nilai sosial kepada tingkat yang lebih berkualitas.

Bahasa selain sebagai bahasa Negara, bahasa juga memiliki sebuah tujuan dari pembelajaran bahasa. Banyak orang yang belajar bahasa dengan berbagai tujuan yang berbeda. Ada yang belajar hanya untuk mengerti, ada yang belajar untuk memahami isi bacaan, ada yang belajar untuk gengsi-gengsian, da nada 
pula yang belajar dengan berbagai tujuan khusus.

\section{Bahasa sebagai Unsur Fiksi}

Bahasa adalah seni sastra yang dapat disamakan dengan cat dalam seni lukis. Keduanya merupakan unsur bahan, alat, sarana, yang diolah untuk dijadikan sebuah karya yang mengandung "nilai lebih' daripada sekedar bahannya itu sendiri. Bahasa merupakan sarana pengungkapan sastra. Sastra, khususnya fiksi, di samping sering disebut dunia dalam kemungkinan, juga dikatakan sebagai dunia dalam kata. Hal ini disebabkan dunia yang menciptakan, dibangun, ditawarkan sekaligus ditafsirkan lewat kata-kata, lewat bahasa. Apapun yang akan dikatakan pengarang atau sebaliknya ditafsirkan oleh pembaca dan harus bersangkut paut dengan bahasa.

Fiksi menceritakan berbagai masalah kehidupan manusia dalam interaksinya dengan lingkungan dan sesame, interaksinya dengan diri sendiri, serta interaksinya dengan Tuhan. Fiksi merupakan hasil dialog, kontemplasi, dan reaksi pengarang terhadap lingkungan dan kehidupan. Walau berupa khayalan, tidak benar jika fiksi dianggap sebagai hasil kerja lamunan belaka, melainkan penghayatan dan perenungan secara intens, perenungan terhadap hakikat hidup dan kehidupan. Fiksi merupakan cerita rekaan karena yang diceritakan adalah peristiwa kehidupan yang pada dasarnya merupakan peritiwa kehidupan hasil rekaan pengarang yang realitasnya tidak terlalu dipersoalkan.

Dalam sebuah karya fiksi itu terdapat berbagai unsur stile diantaranya: unsur leksikal, unsur gramatikal, unsur gaya, retorika dan kohesi. Dan dalam percakapan fiksi ini juga mencakup beberapa hal yaitu: narasi dan dialog, unsur pragmatik dalam percakapan, dan tindak ujar.

Sesungguhnya bahasa akan indah diucapkan dan manis untuk didengar jika bahasa diucapkan dengan baik dan juga beretika. Bangsa Indonesia sejak lama dikenal sebagai bangsa yang ramah dalam bertutur. Dunia internasional telah mengakui hal itu karena bangsa kita sangat menjunjung tinggi etika, baik dalam berbahasa, bersikap, maupun dalam bertingkah laku.

Bahasa sebagai sarana mengungkapkan sastra. Di pihak lain sastra lebih dari sekedar bahasa, deretan kata atau kalimat, namun unsur kelebihannya itupun hanya dapat diungkapkan dan ditafsirkan memulai bahasa. Jka sastra dikatakn ingin menyampaikan sesuatu, mendialogkan sesuatu, sesuatu tersebut hanya dapat dikomunikasikan lewat sarana bahasa. Fungsi utama bahasa adalah fungsi komunikatif (Nurgiantoro, 1993:1).

\section{Bahasa sebagai Unsur Stile}

Stile adalah cara mengungkapkan bahasa dalam bahasa prosa. Stile ini di tandai oleh ciri-ciri formal kebahasaan seperti pilihan kata, struktur kalimat, bentuk-bentuk bahasa figuratif. Makna stile menurut Leech Short (1981: 10). Suatu hal yang ada pada umumnya tidak lagi mengandung sifat controversial, menyaran pada pengertian cara penggunaan bahasa dalam teks tertentu, oleh pengarang tertentu untuk tujuan tertentu dan sebagainya.

Stile pada hakikatnya merupakan teknik, teknik pemilihan ungkapan kebahasaan yang dirasa dapat mewakili sesuatu yang akan diungkapkan. Stile dalam masalah struktur lahir bentuk ungkapan kebahasaan, seperti yang terlihat 
di novel merupakan bentuk peformansi kebahasaan seseorang pengarang, iamerupakan pernyataan lahirlah dari sesuatu yang bersifat batiniah. Jika hal itu dikatikan dengan teori kebahasaannya Saussure, yang membedakan antara langue dengan parole, stile merupakan suatu bentuk parole. Langue merupakan sistem kaidah yang berlaku dalam suatu bahasa, sedangkan parole merupakan penggunaan dan perwujudan sistem, selesi terhadap sistem yang dapat dipergunakan oleh penutur sesuai dengan konteks dan situasi.parole adalah bentuk performasi kebahasaan yang telah melewati proses seleksi dari keseluruhan bentuk kebahasaan. Membaca baris-baris kalimat sebuah novel berarti kita berhadapan dengan struktur lahir, dengan bentuk performasi kebahasaan pengarang. Dengan demikian, berdasarkan teori Chomsky stile tidak lain adalah struktur lahir.

\section{Percakapan dalam Fiksi}

Dalam novel, percakapan terjadi setiap saat sebagaimana pandangan penulis terhadap kenyataan atau imajinasi yang dinyatakan sehingga menimbulkan suatu keanekaragaman tindak tutur, tindak bahasa, dan lain-lain. Disini penuturan dibagi menjadi dua yaitu penuturan langsung dan tidak langsung.

Di dalam fiksi dialog bukanlah segala-galanya. Pengarang seperti Gabriel Garcia lebih banyak mengandalkan narasi, nyatanya dia bisa menulis fiksi dengan baik. Namun, menulis dialog bisa jadi merupakan keterampilan yang sangat dibutuhkan. Karena kebanyakan adegan besar dan adegan kecil bergantung pada dialog.

Percakapan-percakapan muncul dalam cerita karena tentu saja, di dalam kehidupan nyata percakapan juga muncul. Namun dalam kehidupan nyata, banyak dari kita membuat percakapan-percakapan yang tidak penting. Di dalam menulis fiksi kita harus menghindari menuliskan dialogdialog yang tidak penting.

1) Narasi dan dialog

Sebuah karya fiksi umumnya

dikembangkan dalam dua bentuk penuturan yaitu narasi dan dialog. Kedua bentuk tersebut hadir dalam waktu bergantian sehingga cerita yang ditampilkan menjadi tidak bersifat monoton, terasa variatif dan segar. Sebuah novel yang hanya dituturkan dengan teknik narasi saja atau dengan dialog yang amat sedikit, misalnya, di samping terasa monoton juga akan membosankan.

2) Unsur pragmatik dalam percakapan

Percakapan hidup dan wajar, hal itu terdapat dalam sebuah novel, adalah percakapan yang sesuai dengan konteks pemakaiannya, percakapan yang mirip dengan situasi nyata penggunaan bahasa. Bentuk percakapan yang demikian bersifat pragmatik. Dalam situasi nyata, prang mempergunakan bahasa tak hanya berurusan dengan unsur bahasa itu sendiri, melainkan juga dengan unsur-unsur lain di luar konteks bahasa.

3) Tindak ujar

Salah satu hal yang penting dalam interpretasi percakapan secara pragmatic, konsep yang menghubungkan antara makna percakapan konteks adalah konsep tindak ujar, sebuah konsep yang dikembangkan oleh Austin (1962) dan Searle (1969) (lewat Leech \& Shot, 1981: 290). Konsep tersebut berangkat dari adanya kenyataan bahwa, jika seseorang mengucapkan kalimat-kalimat dalam percakapan yang dilakukan umumnya disertai oleh adanya perfom acts yang 
berbeda-beda. Misalnya, penampilan tindak ujar yang berupa penjelasan, pernyataan, permintaan, perintah dan sebagainya.

\section{PENUTUP}

Bahasa adalah alat untuk berkomunikasi yang dapat disampaikan melalui lisan, tulisan maupun media lain yang sudah disepakati oleh pihak yang berkomunikasi. Bahasa yang disampaikan melalui lisan dapat disebut dengan bahasa primer sedangkan bahasa yang diutarakan dengan menggunakan selain lisan disebut dengan bahasa sekunder.

Stile adalah cara mengungkapkan bahasa dalam bahasa prosa. Bahasa merupkan sarana pengungkapan sastra. Sastra, khususnya fiksi, di samping sering disebut dunia dalam kemungkinan, juga dikatakan sebagai dunia dalam kata.

Percakapan terjadi setiap saat sebagaimana pandangan penulis terhadap kenyataan atau imajinasi yang dinyatakan sehingga menimbulkan suatu keanekaragaman tindak tutur, tindak bahasa, dan lain-lain. Disini penuturan dibagi menjadi dua yaitu penuturan langsung dan tidak langsung.
Bahasa dalam masyarakat umum sangat berbeda dengan bahasa yang ada dalam prosa. Walaupun secara tertulis itu sama, akan tetapi sangat berbeda dengan maksud yang akan dituju. Secara tidak langung pengarang berpikiran yang tidak sama dengan pembaca. Oleh karena itu setiap penganalisisan karya sastra khususnya prosa fiksi, pasti derlu adanya analisis bahasa sebelum diterjunkan ke layar lebar.

Dalam bahasa sastra juga perlu terdapat unsur keindahan agar pembaca tertarik untuk membacanya. Jika bahasa yang digunakan bagus atau menarik, apalagi isi cerita yang diceritakan menarik pembaca akan berusaha untuk meniru sikap yang baik seperti yang ada dalam cerita tersebut. Dalam sebuah novel pasti terdapat stile dan stilistika dan stile dan nada.

Dalam sebuah karya fiksi itu terdapat berbagai unsur stile diantaranya: unsur leksikal, unsur gramatikal, unsur gaya, retorika dan kohesi. Dan dalam percakapan fiksi ini juga mencakup beberapa hal yaitu: narasi dan dialog, unsur pragmatik dalam percakapan, dan tindak ujar.

\section{DAFTAR PUSTAKA}

Alwi, Hasan. Dkk. 1988. Tata Bahasa Baku Bahasa Indonesia ed ke 3. Jakarta: Balai Pustaka. Faisal, M. Dkk. 2009. Kajian Bahasa Indonesia SD. Jakarta: Dirjen Pendidikan Tinggi Departemen Pendidikan Nasional.

Mamadiyah. 2013. http://mamadiyah.blogspot.com/2013/11/makalah-apresiasi-fiksi-tentangbahasa.html

Muliadi. 2017. Buku Ajar Telaah Prosa (Sebuah Terapan). Makassar: De La Macca

Nurgiyantoro, Burhan. 2010. Teori Pengkajian Fiksi. Yogyakarta: Gajah Mada University Press

Kemendikbud. 2016. Kamus Besar Bahasa Indonesia. Versi Luring. Jakarta: Badan Bahasa Kemendikbud. 
Rahmanto, B. 1989. Metode Pengajaran Sastra. Yogyakarta: Kanisius

https://www.inirumahpintar.com/2017/01/pengertian-ciri-ciri-bentuk-fungsi-unsur-fiksi.html

Mansyur, Umar. 2016. Pemanfaatan Nilai kejujuran dalam Cerpen sebagai Bahan Ajar Berbasis Pendidikan Karakter. In Mengais Karakter dalam Sastra: HISKI Makassar (pp. 330-339). https://doi.org/10.17605/OSF.IO/Z4T3Y

Mansyur, Umar. 2018. Kiat dan Teknik Penulisan Skirpsi bagi Mahasiswa. INA-Rxiv. https://doi.org/10.31227/osf.io/juds7 